\title{
أثر الدعوة والدعاة في ترسيخ العقيلة الصحيحة
}

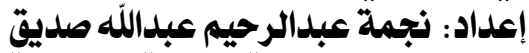

المملكة العربية السعودية

المقدمة

مقام الدعوة في الإسـلام عظيه، بل هي أسساس من أسس انتس هـاره،

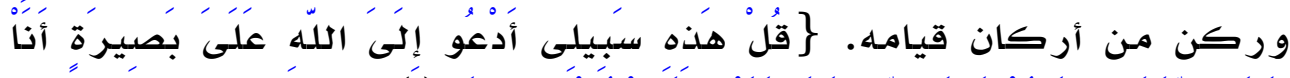

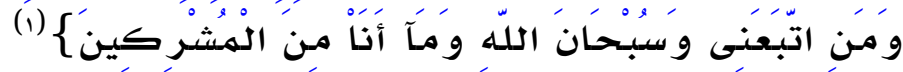

فلو لا الدعوة إلى الله لها قام دين، و لا انتشر إسلام، و لولاها لها

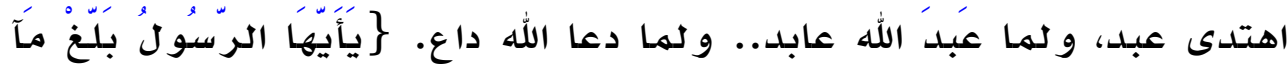

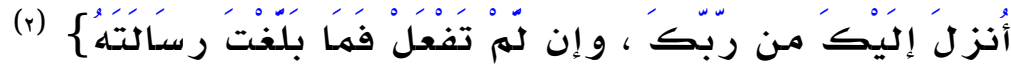
فبالدعوة إلى الله تعالى: يُعبدَ الله وحده، و يهتدي الناس، فيتعلهون أمور دينهم، من توحيد ربهم، وعبادته، وأحكامه من حلال وحرام، و يتعلمهون حلدود ما أنزل الله. وبالدعوة إلى الله تعالى: تستقيم معامـلات الناس، مـن بيع وشراء، و عقود، و نكاح، و تصلح أحوالهم الاجتمـاعيـة و الأسـرية. و بالدعوة إلى الله تعالى: تتحسن أخلاق الناس، وتقل خلافاتهم، و تزو ل أحقادهه و ضغائنهم، ويقل أذى بعضههم لبعض. وإذا مـا قامت الدعوة على وجهها الصحيح، واستجاب الناس لها، تحقق للدعاة و للمددعوين سعادة الدنيا و الآخرة.

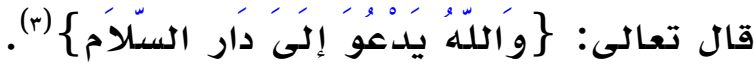

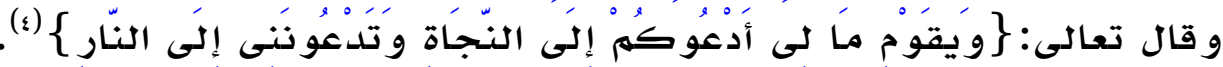

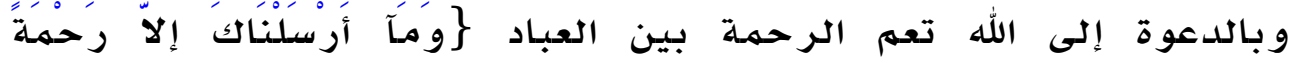

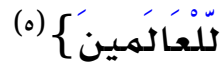

سورة يوسف ، الآية م+1.

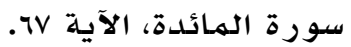

سورة يونس، الآية ro.

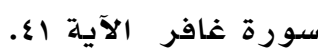

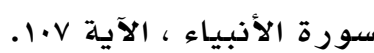




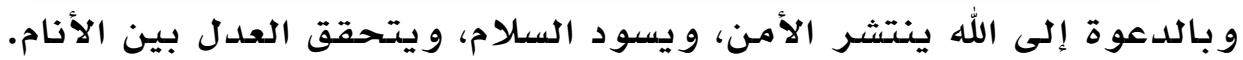

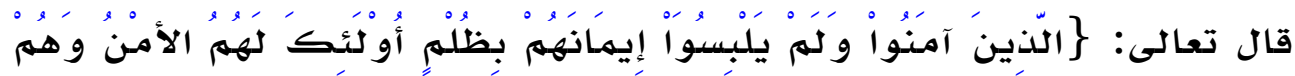

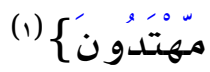

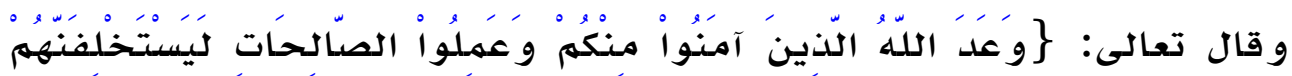

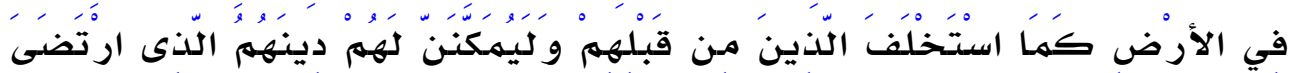

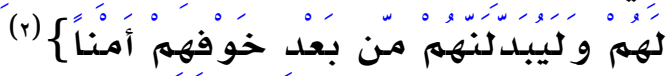

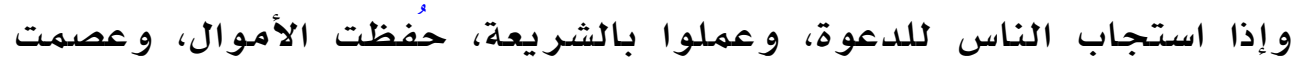

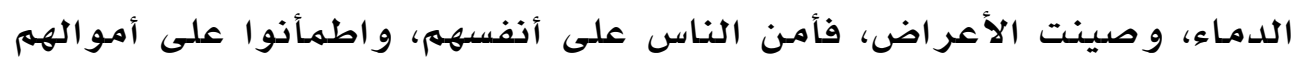

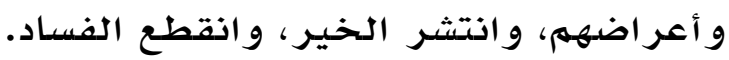

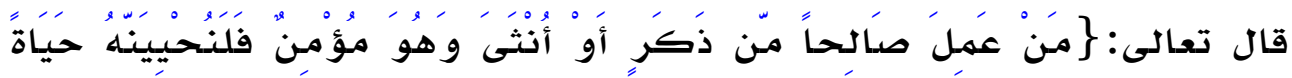

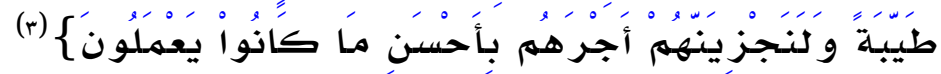

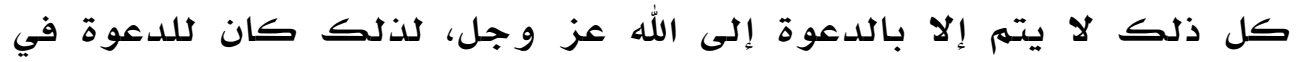

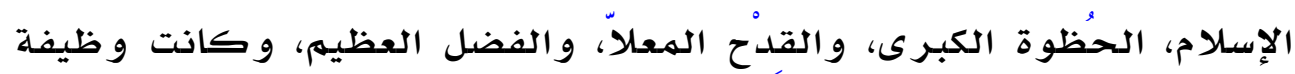
الأنبياء الأو لى. الأسام، الحفوة

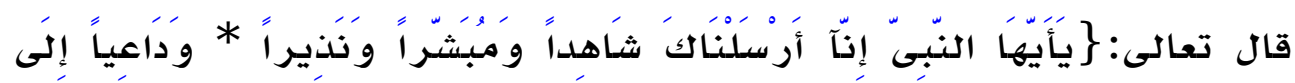

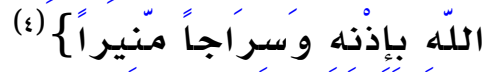

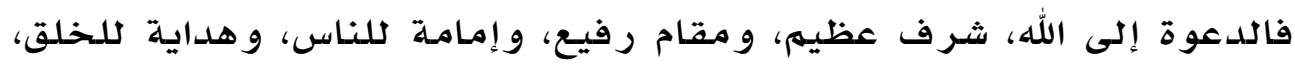

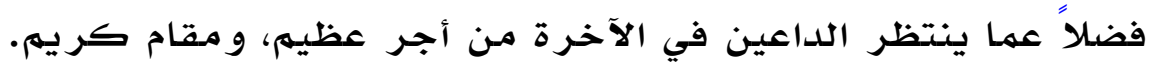

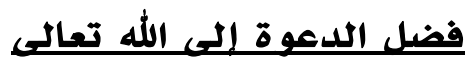

و لِما كان للدعوة من أهمية بالغة في دين الله، و أثر كبير في

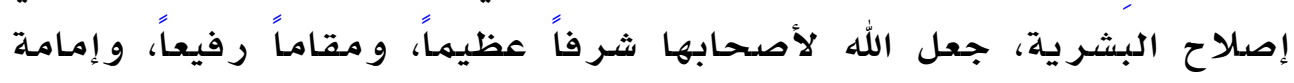




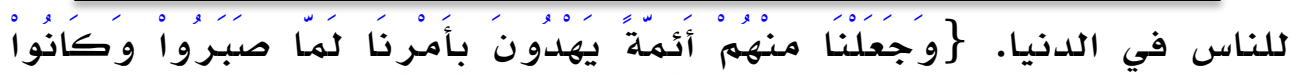

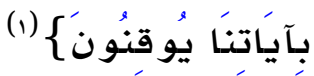

و فضلا" عن هذا كله، جعل الله لصاحبها أجراً عظيها، ومنزلة

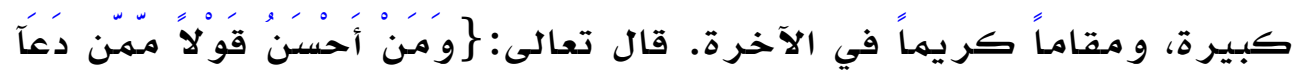

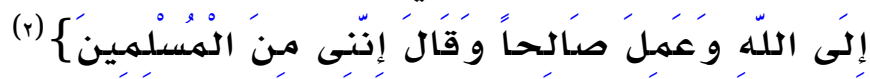

فهذا النص يقرر: أن الدعوة إلى الله الهقرونة بالعهل الصالح، من

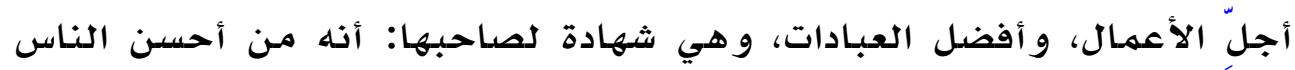
ديناً، و أقو مههم طر يقا.

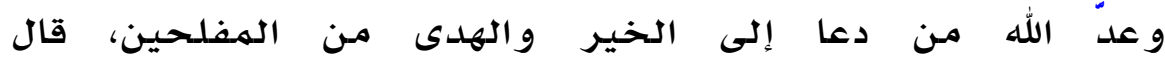

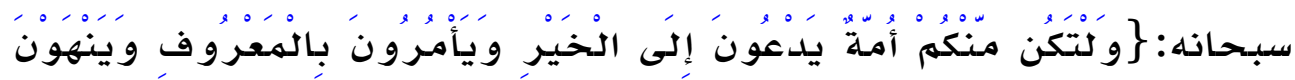

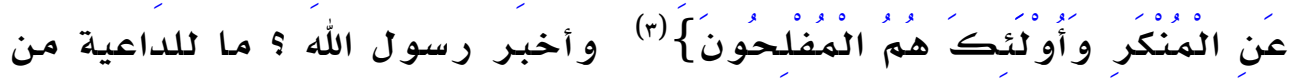
خير، فقال ؟ لعلي رضي الله عنه - في حديث طويل - "فوالله لأن يهدي الله

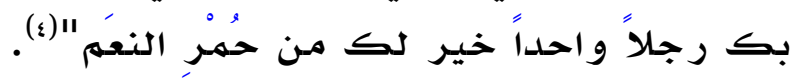

وحمـر النعهم: ((هي الإبل النفيسـة)(ه) (هيل.

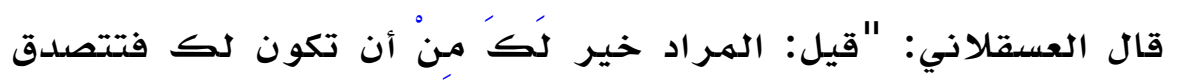

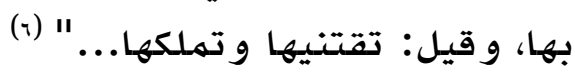

و قد أخبر رسول الله ؟ مـ للداعية من أجر عظيه، وثواب دائه،

و نماء في أجره، و تعاظم في ثوابه، مـادام أثر دعوته قائهما، و نفعها جاريًا.

1.1

$$
\begin{aligned}
& \text { (1) سورة السجدة ، الآية £ץ. }
\end{aligned}
$$

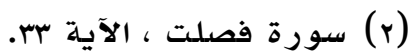

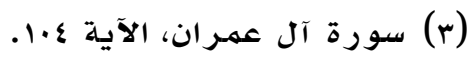

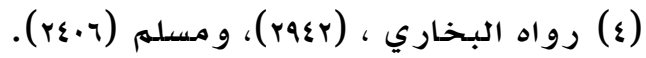

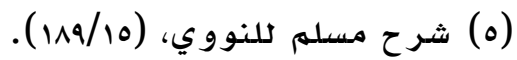

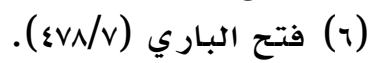




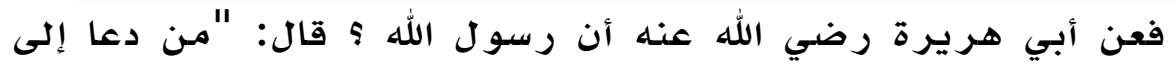
هدى كان له من الأجر مثل أجور من تبعه، لا ينقص ذلكي ذلك من أجورهم

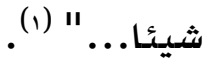

فكل دعوة يقوم بها الداعي يؤجر عليها، و إن لهم يستجب المدعوون،

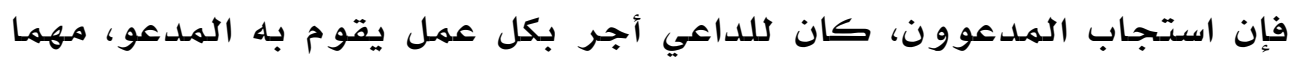

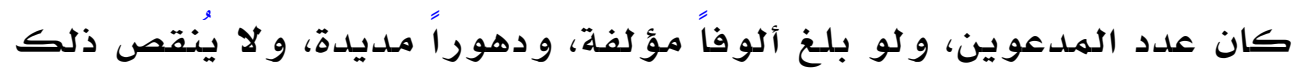
من أجر الهمدعوين شيئا.

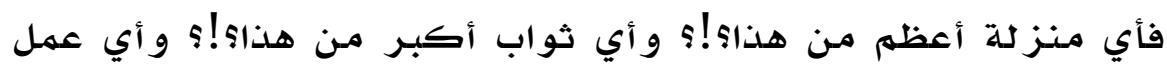

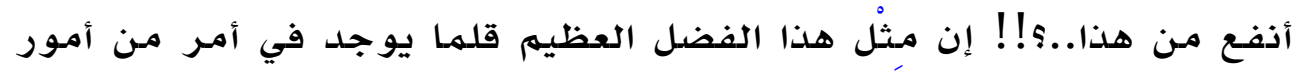

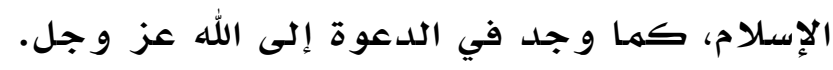
حكم الدعوة إلى الله تعالى دلت نصوص الكتاب والسنة على وجوب الدعوة إلى الله - بمعناها

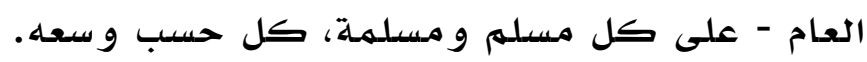
والوسع يشهل: الوسـع العلهي، و الهمالي، والبدني، والقدرة على أدئ أداء

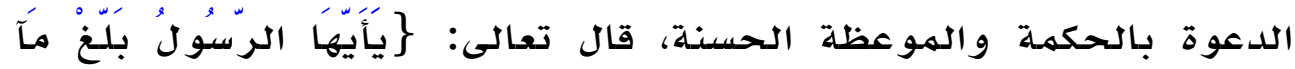

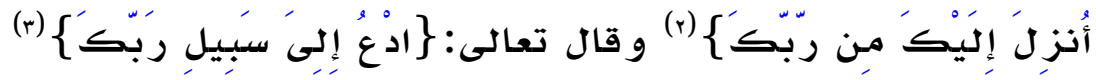

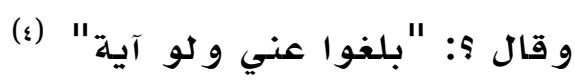

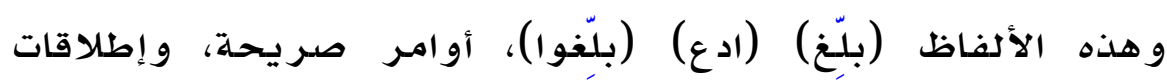

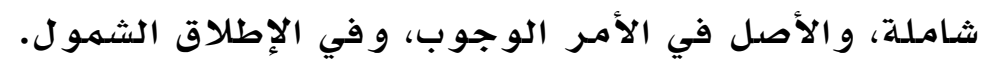
فهي توجب الدعوة على كل مسلهم و مسلمهة، كُكاً في حدود و سعه.

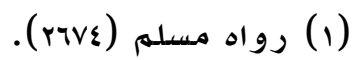

$$
\begin{aligned}
& \text { (Y) سورة المائدة: آية (Y) (Y) (Y) }
\end{aligned}
$$

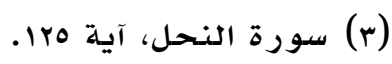

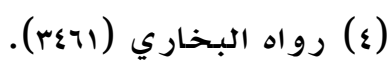


ويتأكد هذا الوجوب على طائفة من الناس، أن تقوم بالدعوة إلى

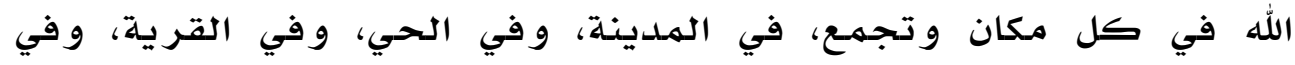

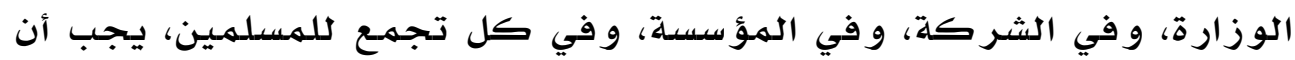

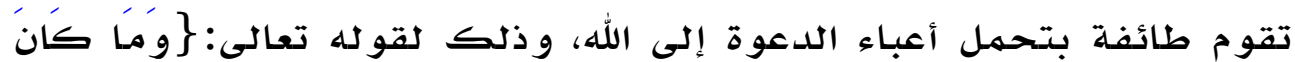

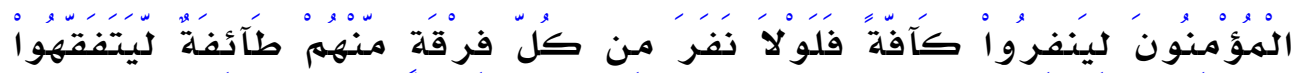

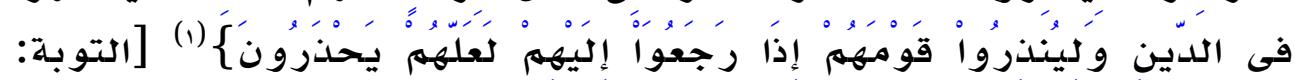
[IrY

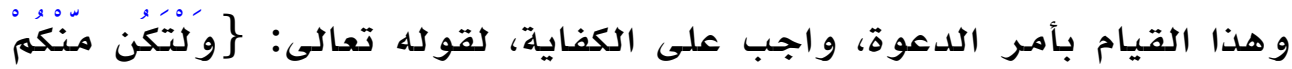

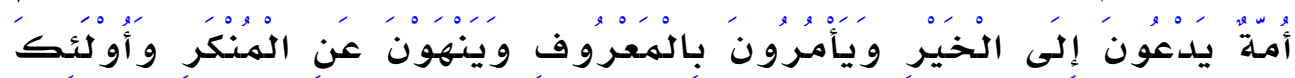

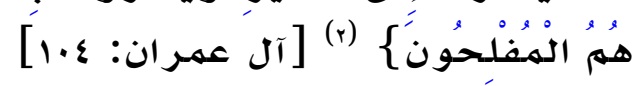

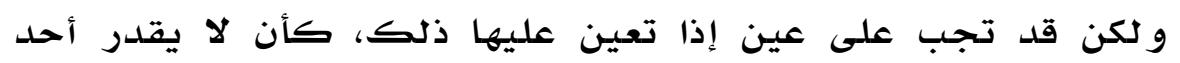
غيره على تبليغ أمر مـا، أولم يقم بـه أحلد.

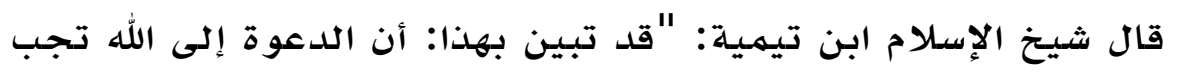

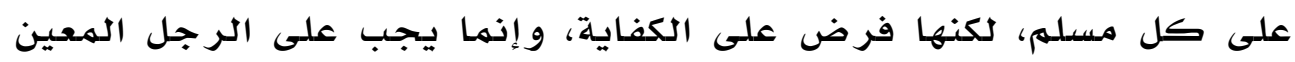

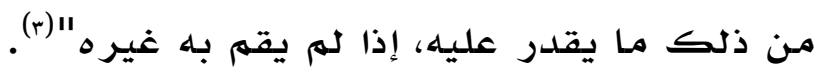

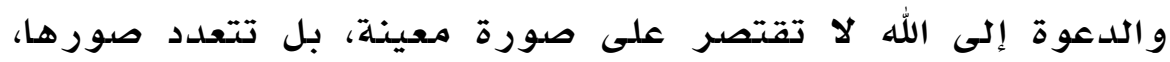
وتتنوع سبلها. فمن عَلَم آيةً فبلغها، فقد دعا إلى الله، ومن حفظ حديثاً فنشره بين الناس، فقد دعا إلى الله.

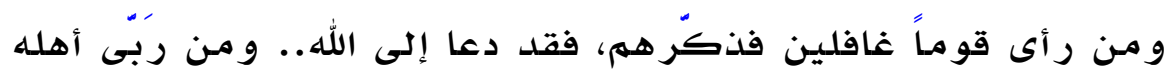

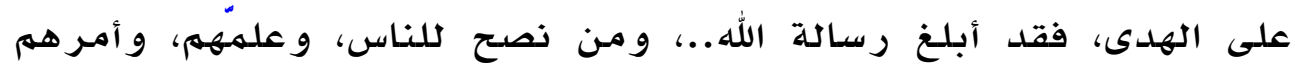

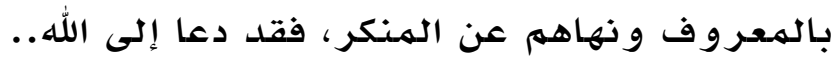

$$
\begin{aligned}
& \text { سورة التوبة، الآية rrا. } \\
& \text { سورة آل عمر ان، الآية ع.ا. }
\end{aligned}
$$

(r) مجموع الفتاوى، تقي الدين أبو العباس أحمد بن بن عبدالدالحليه بن تيمية، المحقق:

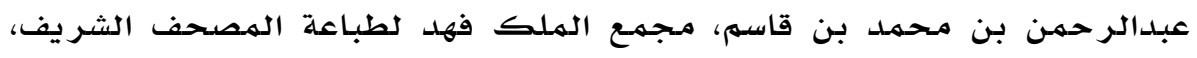
$1 \cdot r$

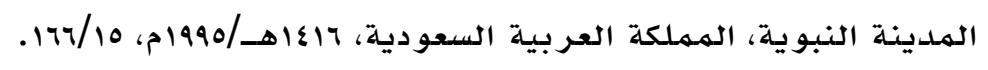


ويزداد عظهم المسؤو لية، كلها ازداد علم المرء، وقدرته، و منزلته بين النناس.

وكلهما ازداد العله، والدعوة، والمسؤولية، ازداد الأجر، وارتفع القدر، و نيلت الدر جات.

الفكرة التجريلية:

أثر الدعوة والدعاة في ترسيخ العقيدة الصحيحة: تعريف الدعوة لغة واصطلاحاً: أو لاً: الدعوة لغة: مشتقة مـن الفعل الثثلاثي دعا يدعو دعوة، والاسهم: الدعوة، و القائم بها يسهـى داعيـة، و الجهـع: دعاة. و لكلمة الدعوة في اللغة عدة معان: النداء، و الطلب، و التجهمع، و الدعاء، و السؤال، و الاستمهالة. قال الزمخشري: "دعوت فلاناً وبفلان ناديته و صسحت بـ" (1). وقال ابن منظور: الدعوة: المـرة الواحدة مـن الدعاء ومنـه الحديث: "فإن دعوتهم تحيط من ورائهم"(ץ)، أي تحوطهم و تكنفهم و تحفظهم يريد أهل السنـة دون البدعة. و الدعاء: واحد الأدعية، و أصلـه دعاو لأنه من دعوت، إلا أن الواو لهـا جاءت بعد الألف همزت.... ودعا الرجل دعوا ودعاء: ناداه،

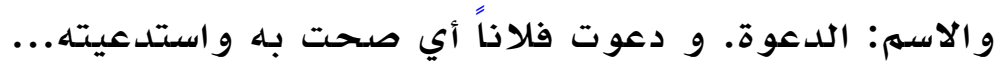
و الدعاة: قوم يدعون إلى بيعـة هدى أو ضلالة، و أحدهم داع. ورجل داعية إذا كان يدعو الناس إلى بـدعة أو دين، أدخلت الهاء فيـه للهبـالغة (r).

(1) أسـاس البـلاغة، أبو القاسهم الزمخشري، دار الفكر ، ط99هاهـ/9V9م، 119/1 .

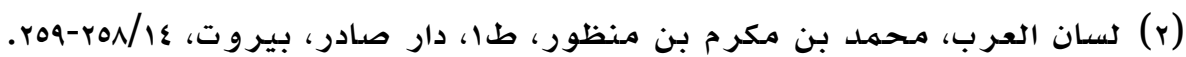

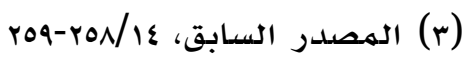




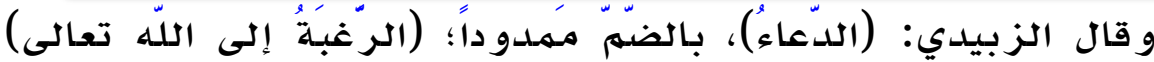

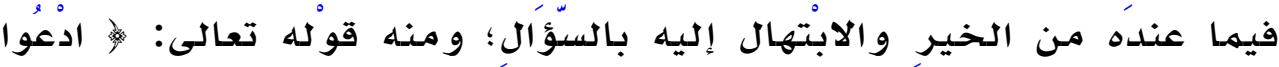

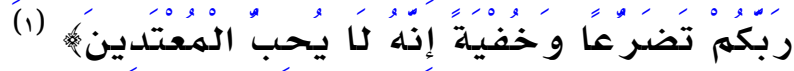

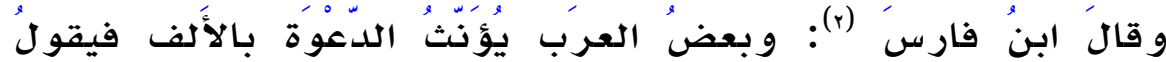

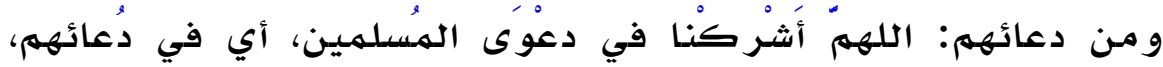

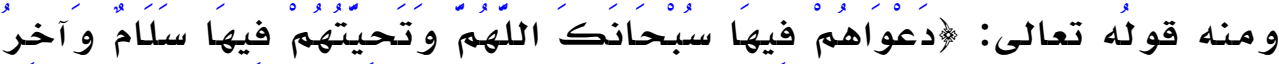

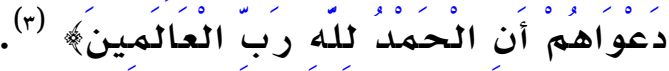

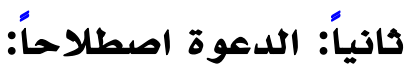
كلمهة الدعوة من الألفاظ المشتركة، فإنه يراد بها في الغالب معنيان: الأو ل: اللدعوة بمعنى الإسـلام أو الرسالة. الثاني: الدعوة بمعنى عملية نشر الإسلام وتبليغ الرسالة. و على المعنى الأول: (الدعوة بمعنى الإسدلام أو الرسالة) جاءت تعريفات اصطلاحية كثيرة، و منها: قيل: هي دين الله الذي بعث به الأنبياء - عليهم الصلاة و السلام - جميعاً،

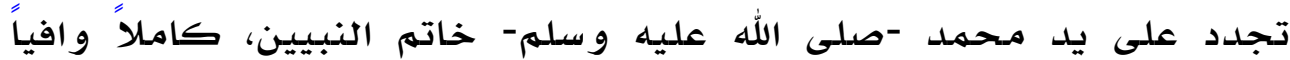
لصلاح الدنيا و الآخرة.

و قيل: هي دين الله الذي ارتضاه للعالمين؛ تهكيناً لخلافتهم، وتيسيراً

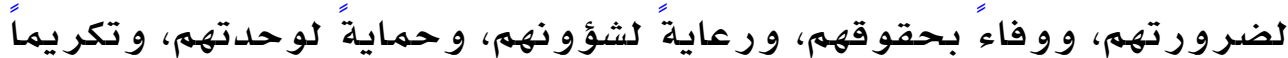

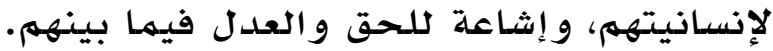
و قيل: هي الضوابط الكاملة للسلوك الإنساني، وتقرير الحقوق والواجبات.

$$
\text { سورة الأعر اف، الآية } 1(1)
$$

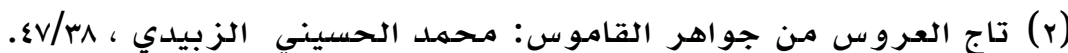

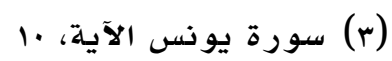


و هي قبـل ذلك و بعده: الاعتر اف بـالخـالق، و البـر بـالهـخلوق(1).

وقيل: هي نداء الحق للخلق؛ ليوحدوا الهعبود، و يعبدوا الواحد،

حنفاء لله غير مشر كين بـه، متبعين غير مبتدهين (r).

و أما على المعنى الثاني: (الدعوة بهعنى عملية نشر وتبليخ الإسلام) فجاءت أيضاً على تعر يفات كثيرة، و منها:

عرّها شيخ الإسـلام ابن تيميـة - رحمه الله تعالى - بقوله الدعوة

إلى الله: هي الدعوة إلى الإيهان بـه وبهما جاءت بـه رسله بتصديقهم فيها أخبرو ا به و طاعتهم فيما أمـروا و ذلك يتضهن الدعوة إلى الشهادتين و إقام الصدلاة وإيتاء الزكاة وصوم رمضان وحج البيت و الدعوة إلى الإيهان بالله و مهائكته وكتبه ورسله و البعث بعد الهوت والإيهان بالقدر خيره وشره

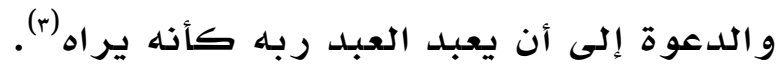

وقيل: هي تبليغ الإسـلام للناس، وتعليهـه إياهم، وتطبيقه في واقع الحياة(؛). وقيل: هي قيام مـن له أهليه، بلدعوة الناس جهيعاً، في كل زمان ومكان، لاقتفاء أثر رسول الله - صلى الله عليه وسلهم- و التأسي بـه، قولاً و عملاً و سلو كاً (0)

وقيل: هي إبلاغ الناس دعوة الإسلام، في كل زمان و مكان، بالأساليب و الوسـائل، التي تتناسب مـع أحوال الهـل الهدعوين (1).

(1) الدعوة الإسـلامية دعوة عالهية، مححمد عبدالرحمن الراوي، ط المبام، الدار القومية

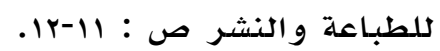

(r) التخطيط للدعوة الإسلامية وأهميته، عبدرب النبله النبي علي أبو السعود، دار التوفيق

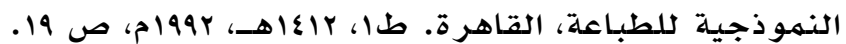

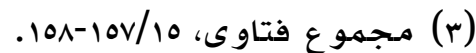

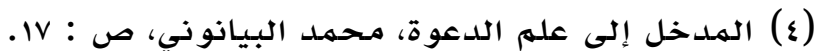

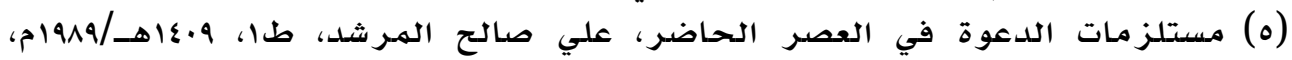

1.7

$$
\text { مكتبة لينه ، دمنهور ، مصرة في العمر الحاضر، صوات }
$$


وقيل: هي قيام الداعية المؤهل بإيصال دين الاسلام إلى الناس كافة، وفق

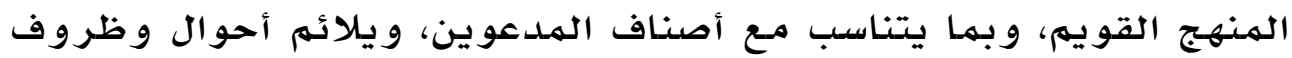

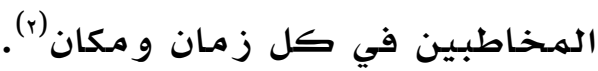
والمعنى الثاني: وهو (عملية النشر والتبليغ) هو المقصود بالحديث: العقيدة في اللغة : ماخوذة من العقد، وهو الربط والشد بقوة(ץ). واصطلاحاً: لها تعريفان:

\section{أو لاً: التعر يف الاصطلاحي العام:}

عُرِّت العقيدة وفق المفهوم العام بأنها: ما يعقد عليه الإنسان قلبه،

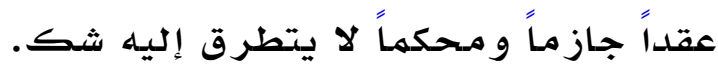
ثانياً: تعر يف العقيدة الإسلامية:

هي: 》الإيمان الجازم بالله، وما يجب لله في ألوهيته وربوبيته

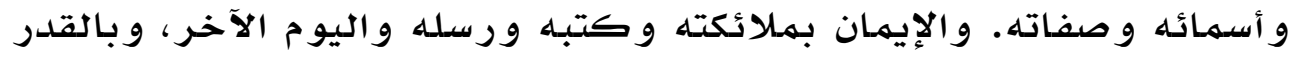
خيره وشره، و بكل ما جاءت به النصوص الصحيحة من أصول الهـ الدين و أمور

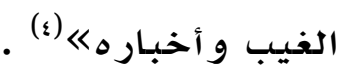

أهمية العقيدة الإسلامية:

للعقيدة الإسلامية أهمية كبيرة تظهر في الأمور التالية:

(1) الدعوة والإنسان، عبدالله يوسف الشاذلي، طا، المكتبة القومية الحديثة، طنطا، ص94.

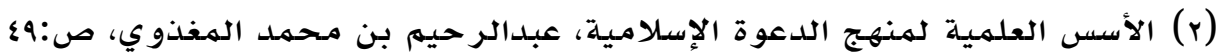

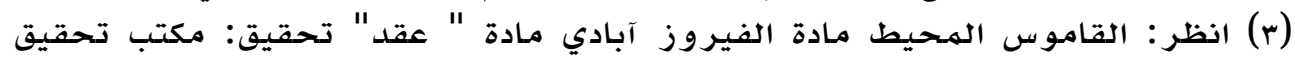

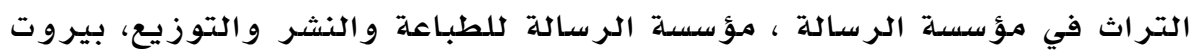

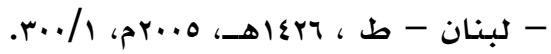

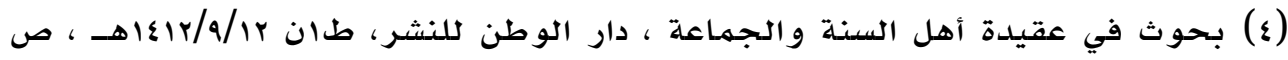
$1 \cdot V$ 
ا- أن جميع الرسل أرسلوا بالدعوة للعقيدة الصحيحة، قال الله تعالى:

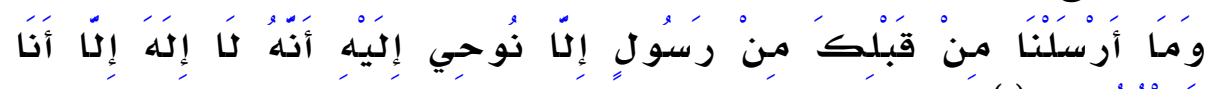

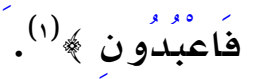

ץ- أن تحقيق توحيد الألوهية و إفراد الله بالعبادة هو الغاية الأولى من

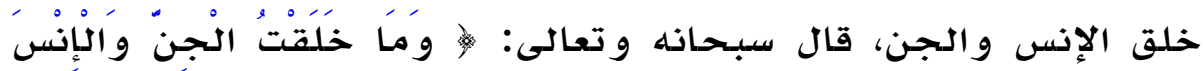

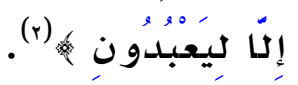

ץ- أن قبول الأعمال متوقف على تحقق التوحيد من العبد، وكمال

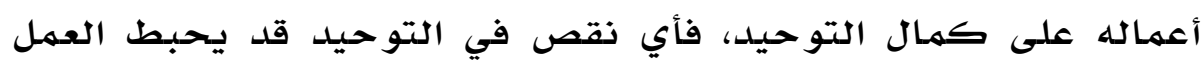

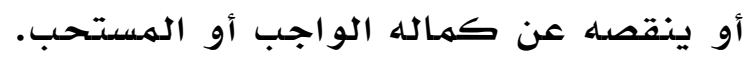

ع- أن النجاة في الآخرة - ابتداءً أو مآلاً - متوقفة على صحة العقيدة،

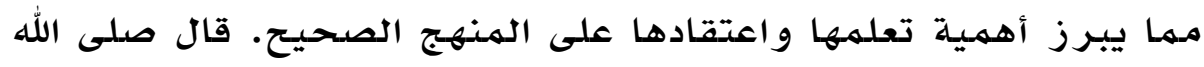

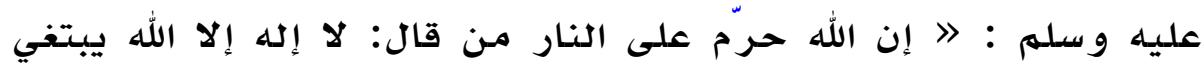
بذلك وجه الله

ه- أن هذه العقيدة تحدد العلاقة بين العبد وخالقه: معرفة، وتوحيدًا،

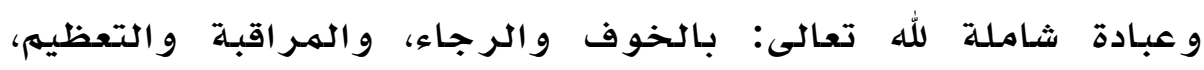

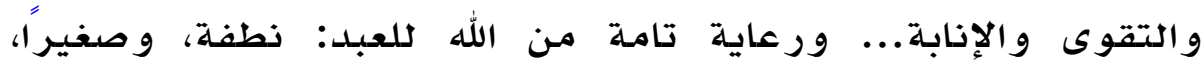
وكبيرًا، في البر و البحر ، رزقاً و وإنعاماً، وحفظاً و وعناية.

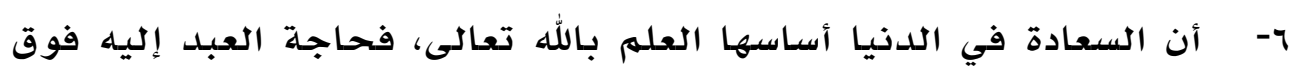

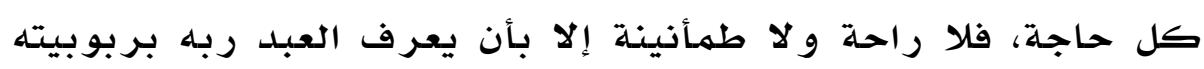
و ألو هيته و أسمائه و وصفاته واحة ولاته

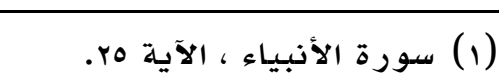

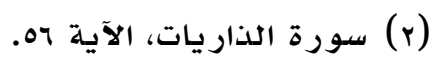

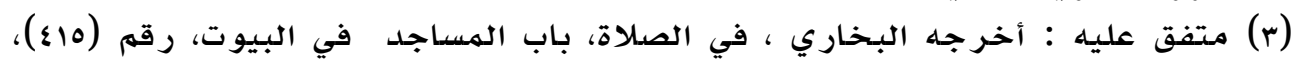
$1 \cdot \Lambda$

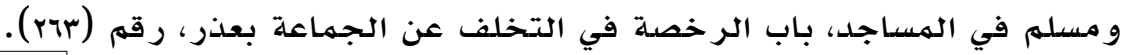


V- أن هذه العقيدة تجيب عن جهيع التسـاؤ لات التي ترد على ذهن العبد، ومن ذلك: صفة الخالق، ومبدأ الخلق، ونهايته، و غايته، والعواله

الكائنة في هذا الوجود، و العلاقة بينها، و مو ضوع القضاء و القدر ...

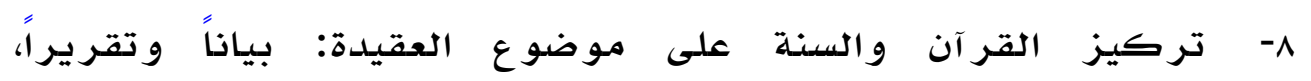

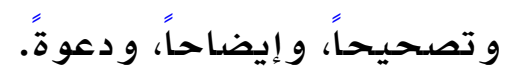

ه- أن العقيدة الصحيحة سبب الظهور و النصر والفلاح في الدارين، فالطائفة الهتمسكة بها هي الطائفة الظاهرة والناجية والمنصورة التي لا يضرها من خذلها. قال -صلى الله عليه وسلهم-: الا تزال طائفة من أمتـي ظاهرين على الحق، لا يضـرهم مـن خذلههم حتى يأتي أمر الله وهم كذ كنه (1)

• ا- العقيدة الصحيحة هي ما يعصدم المسلهم من التأثر بها يحيط بـه مـن عقائد و أفكار فاسلدة.

و في الجملة فإن الالعقيدة الصحيحة هي الأسـاس الذي يقوم عليه

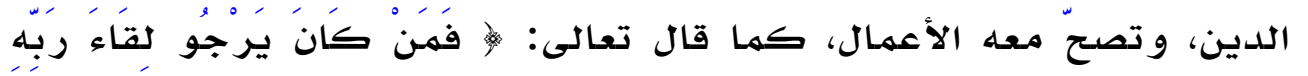

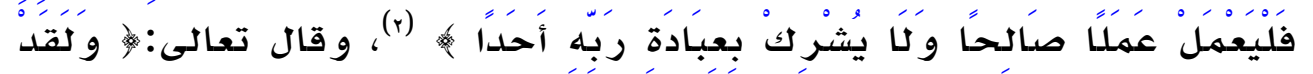

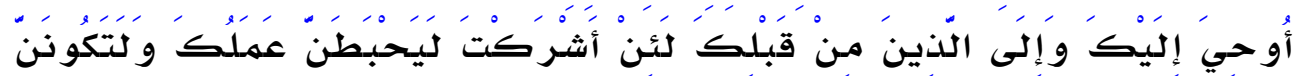

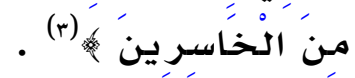

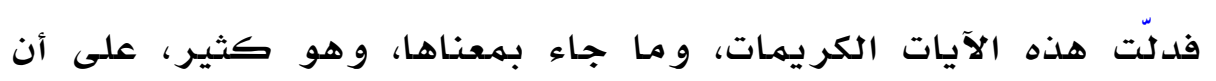

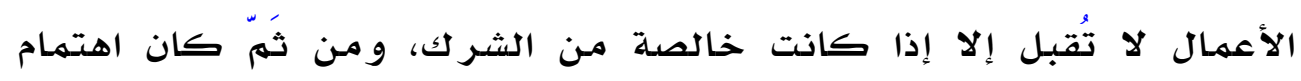

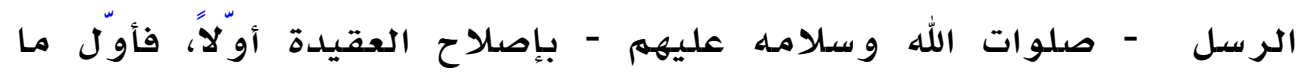
يلدعون إليه أقوامهم هو عبادة الله وحلده، وترك عبادة ما سواه، كها قال

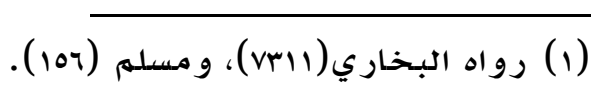

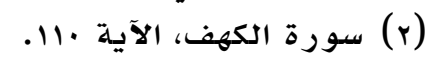

$$
\begin{aligned}
& \text { (r) سورة الزورة الزعف، الآية ، الآية، } 10 .
\end{aligned}
$$




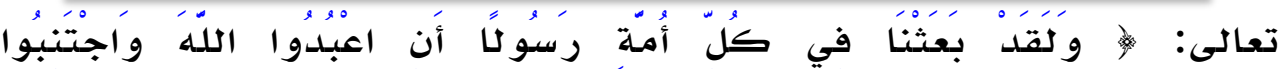

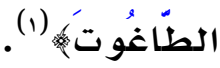

وقد بقي النبي -صلى الله عليه و سلهم- في مكة بعد البعثة ثلاثة عشر عامـاً يـعو الناس إلى التوحيد، وإصلاح العقيدة؛ لأنها الأسـاس الذي يقوم عليـ بناء الدين. وقد احتذى الدعاة والمصلحون في كل زمان حذو الأنبياء و المـرسلين، فكانوا يبدؤون بالدعوة إلى التوحيد وإصلاح العقيدة، ثم يتجهون بعد ذلك إلى الأمـر ببقية أوامر الدين «اع).

الدعوة إلى الله عز وجلَ مـن أفضلَ الأعمال، ووأقرَبَ القربات،

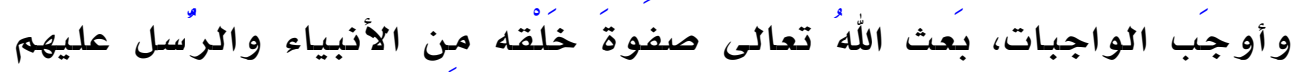
الصلاة و السـلام للقيام بها، ووَعَد القائمين بها أجرًا عظيهًا، و ثوابًا جزيلًا في الدنيا والآخرة، بل إن الله جل وعلا جعَلها شعارًا لأتبـاع الرسل عليهم

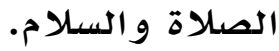

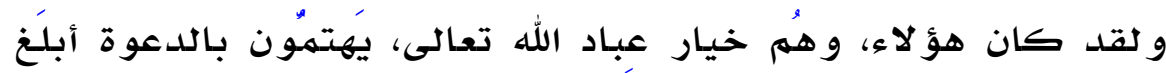
الاهتهـام، ويحر صون على إخراج الناس من الظلهمات إلى النور أشد

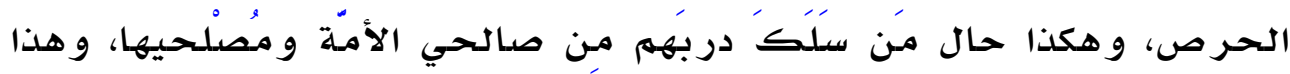
الاهتمام الهلحوظ ير جـع لأسبـاب؛ منهـا:

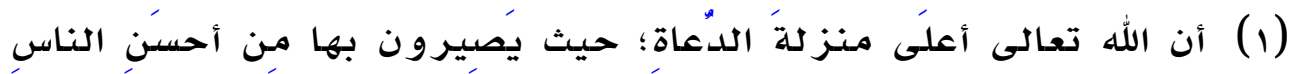

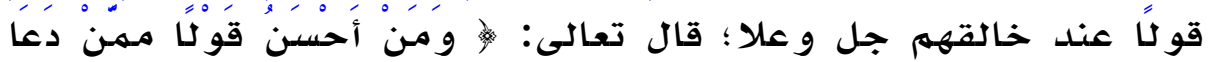

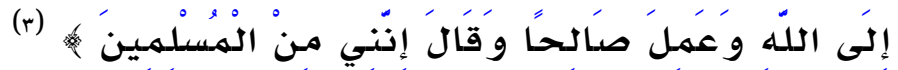

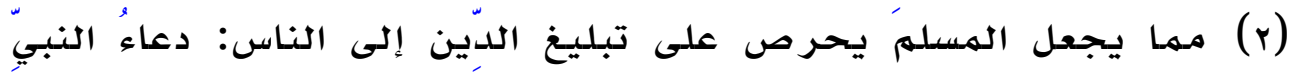

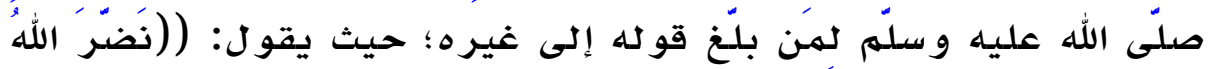




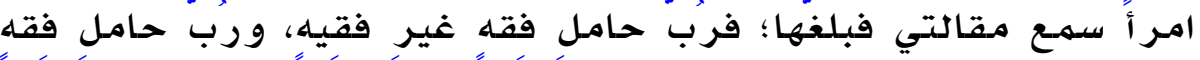

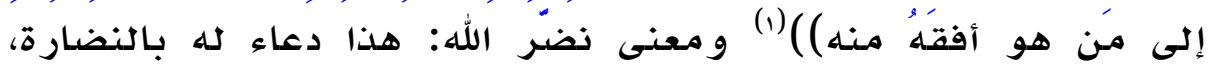
و هي النعمهة و البهجة.

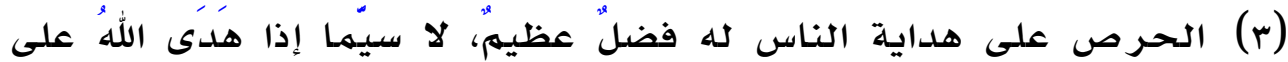
يده أحدا، يدل لذلك مـا ثبت عن سهل بن سعد السـاعدي رضي الله

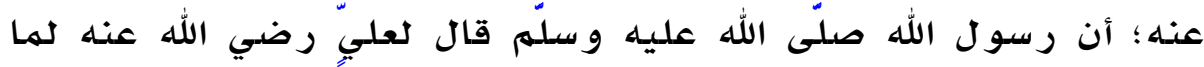

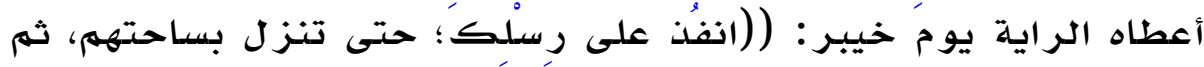
ادعهمه إذى الإسـلام، وأخبرهم بهما يجب عليهم مـن حقّ الله فيـه، فوالله

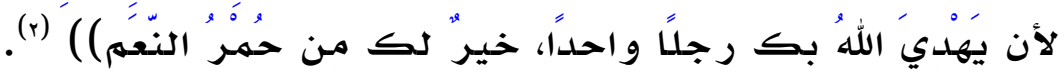

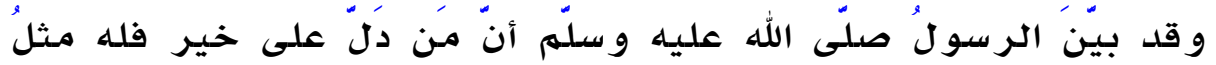
أجر فاعله؛ فقد روى ابن مسعود رضي الله عنه، قال: قال رسول الله صلّى

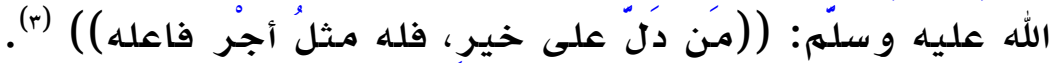
العقيدة الإسـلاميـة منهج متهـيز في تلقّيها و أخذها، و وكذلك الاستـلالال عليها وهو منهج السلف من الصحابة و التابعين لهم بإحسان، من

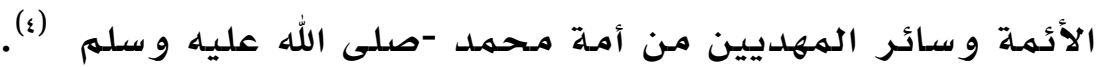
أوّ"اً: منهج تلقي العقيدة عند السلف يقوم على عدة أسس، منها: ا- الاقتمسار في منهج التلقي على الوحي:

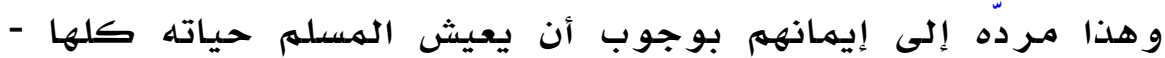
اعتقاداً و عمهلاً و سلوكاً - مستهمسكاً و معتصهماً بالوحي المتهمثل في الكتاب

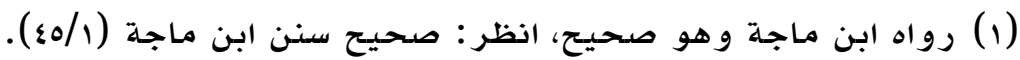

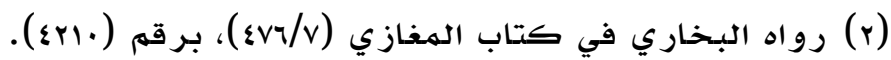

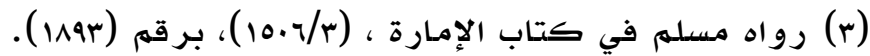

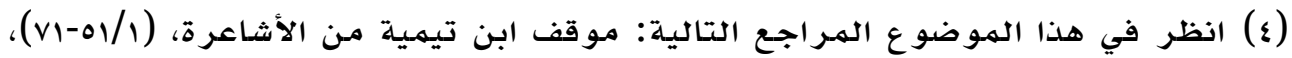

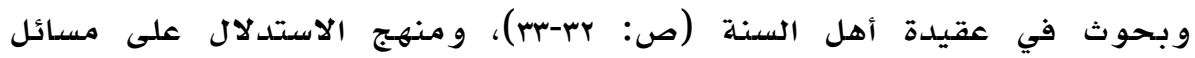




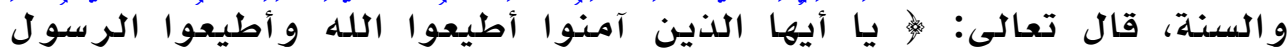

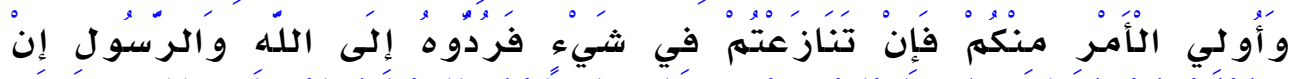

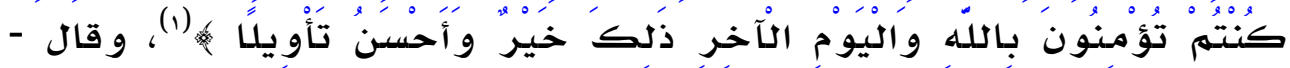

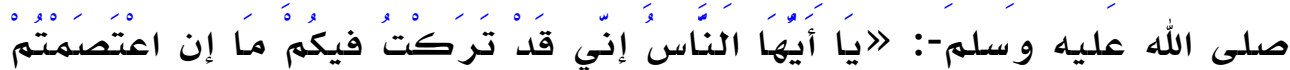

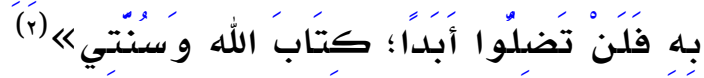
و لهذا كان رسول الله -صلى الله عليه وسلهر- يحذرهم الالتفات إلى كتب السـابقين التي دخلها التحر يف. ץ- التسليم لما جاء به الوحي، مـ إعطاء العقل دوره الحقيقي: مها يمـيز الهسلمين الذين يؤمسنون بهما جاءت بـه العقيدة الإسلاميلة، أنهم آمنوا بهذه العقيدة على الغيب، وقد جاء مدح هذا الإيهمان في القر آن

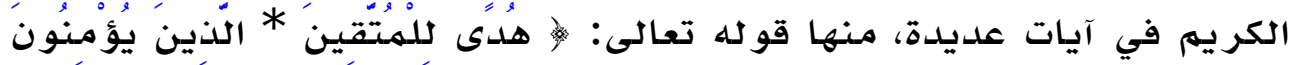

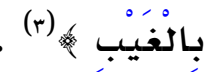
و لها كانت العقيدة تقوم على الأمور الغيبيـة، كان مبنـاها على التسليهم بها جاء عن الله جلّ جلاله، وعن رسوله -صدى الله عليه وسلهمظاهراً و باطناً، مـا عقلناه منها و مـا له نعقله . فوظيفة العقل تتوقف عند التدبر في آيات الله، ومعرفة محاسن العقيدة والشريعة التي جاء بها الإسـلام، كما أنه هو الآلكة في فهم النصوص الشرعية واستخخلاص المعاني الهـر ادة مـنها. r- ترك الابتداع:

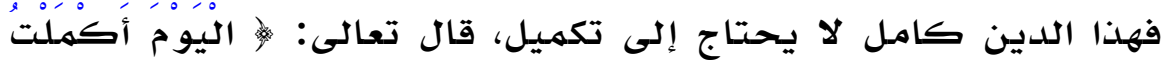

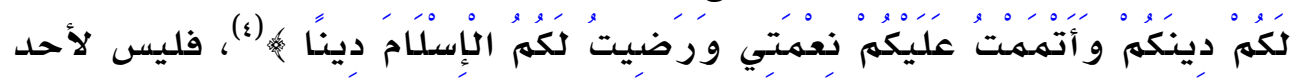

$$
\begin{aligned}
& \text { (1) سورة النسساء ، الآيـة } \\
& \text { أخرجه مالك في الهوطأ، باب النهي عن القول بالقدر، رقهم (177اء). }
\end{aligned}
$$

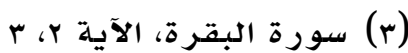

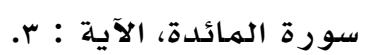


أن يحدث في هذا الدين أمراً له يأت في الكتاب أو السنـة، قال -صلى الله

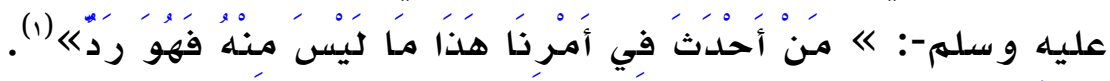

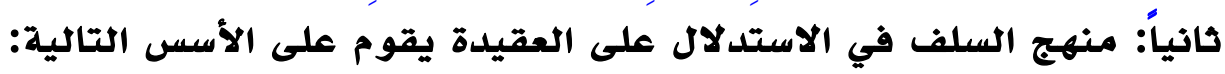
ا- حجية السنة ( المتواترة والآحاد) في العقيدة:

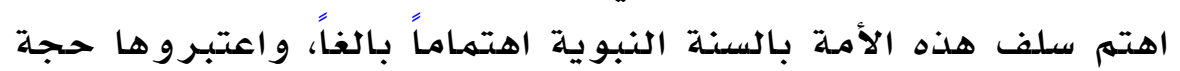

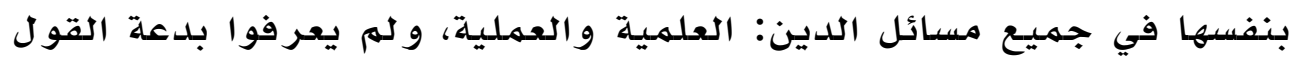
بالتفر يق بين السنة المتواترة و السنة الآحادية في الاحتجاج. وهذا مبني عندهم على أسس، منها:

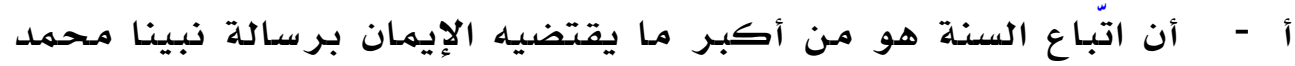
-صلى الله عليه وسلهم-.

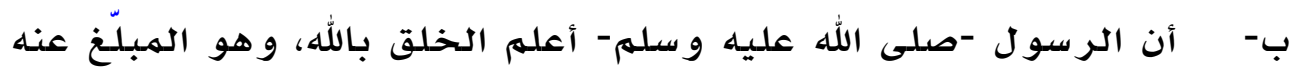

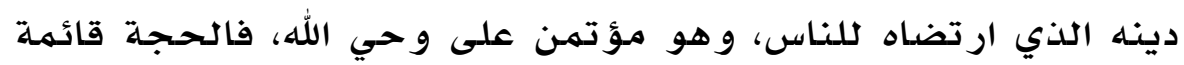
فيما يبلّغنه كله.

ج- أن الرسول -صلى الله عليه وسلهم- بلّغ جميع الدين و لهم يكتم منهـ

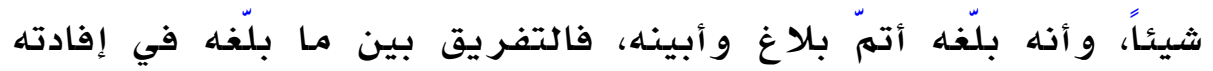

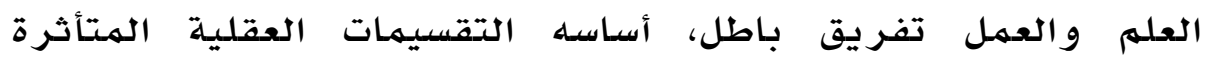

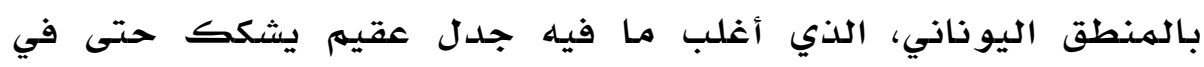
البديهيات.

r- ترك التأويل المذموم لنصوص الكتاب والسنة:

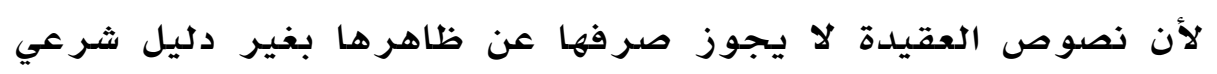

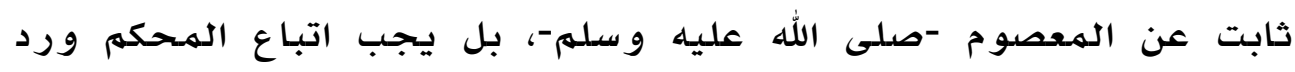
الهتشابـه إليله.

r- عدم التفريق بين الكتاب والسنة في الاستدلال:

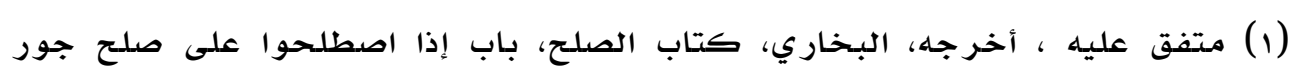

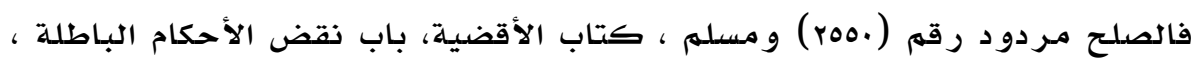


فالكتاب والسنة وحي من الله تعالى، و القبول ل لهما واجب على حدّ

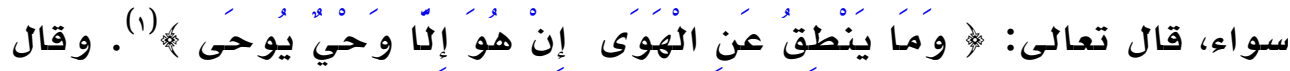

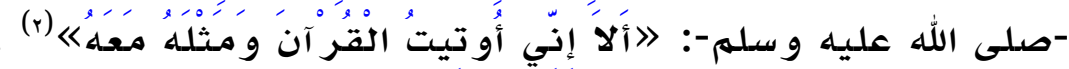

\section{ع- صححة فهم النصوه (r):}

فصحة فهم النصوص ركيزة أسساسية لصحة الاستدلال، و لا يستطيع الهـرء معر فة مر اد الله تعالى، ومـراد رسوله -صلى الله عليه و سلهم- إلا حينها يستقيهم فهمه لدلائل الكتاب والسنة، وخاصدة في هذا العصر الذي كثر فيه الهتحدثون في أمور الدين عبر وسائل الإعلام الهـتلفة؛ كالفضائيات و الإنتر نت، فالهعرفة بهذه القواعد الأسـاسية التي يرتكز عليه الفهم الصسحيح تمكّن من تهييز المتحدثين بحق من المنحر فين عن الفهه الصحيح، وركائز الفهم الصحيح للنصوص صثيرة منها: أ - معرفة لغة العرب التي نزل بها القر آن وتكله بها النبي -صلى الله عليه و سلهم.

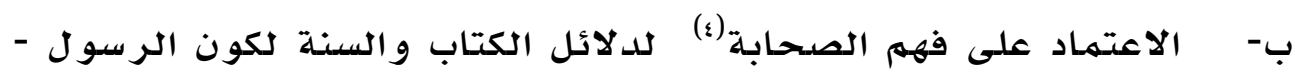
صلى الله عليه و سلهم- بين أظهر هم، كهما عايشوا نزول الوحي، فهم

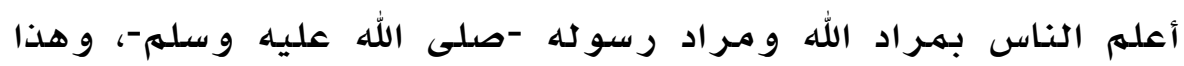
الأمـر يتأكد خاصدة إذا كثرت البدع و الأهواء، قال رسول الله -صدى

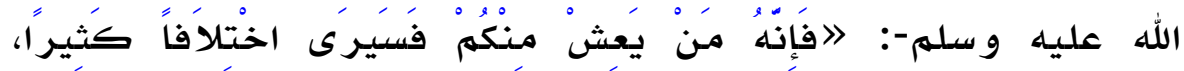

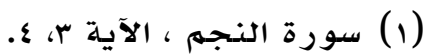

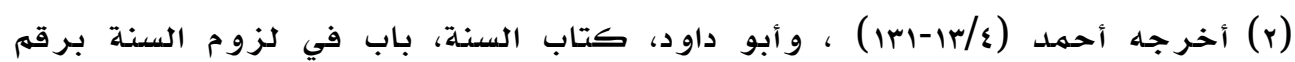

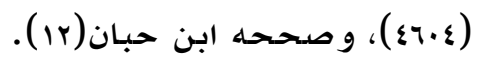

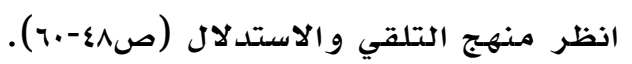

(ع) ما أبلـغ ما وصف بـه اب مسعود أصحاب رسول الله صلى الله عليه وسلهم حين قال:

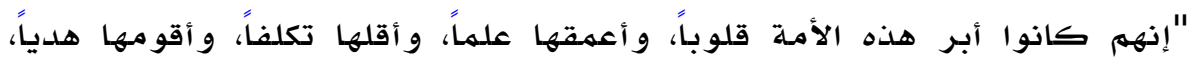

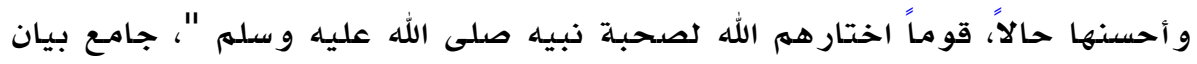
$11 \varepsilon$

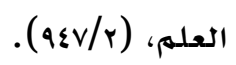




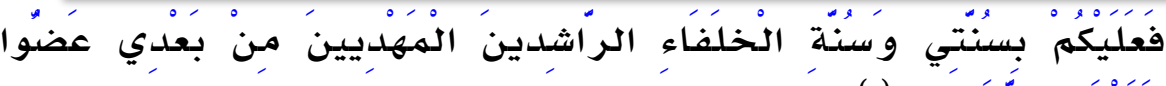

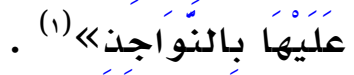

ج- جهع النصوص الواردة في الهسألة الواحدة، ثم الأخذ بها جهيعاً، فلا يعطلون بعض النصوص و يُعملون أخرى.

د- معرفة مقاصد التشريع الإسلامي: قال شيخ الإسلام ابن تيهية: االشريعة مبنـاها على تحصيل المصالح وتكميلها، وتعطيل الهفاسلد و تقليلها بحسب الإمكان، و معر فة خير الخيرين و شـر الشرّين، حتى

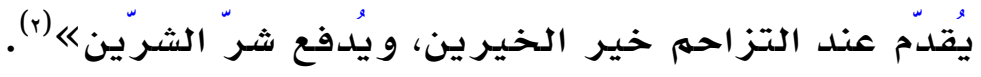

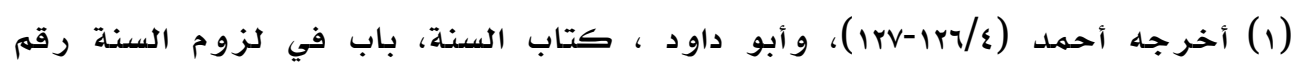

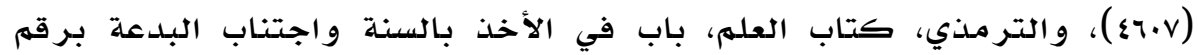

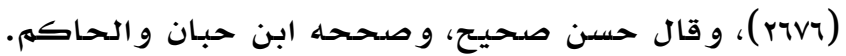

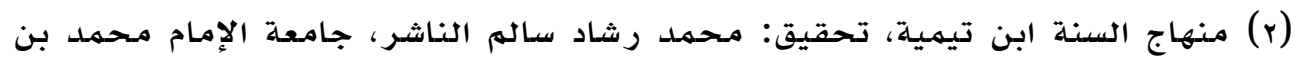
110

$$
\text { سعود الإسـلادية طا، 7. +عاهـ. }
$$


الننتائحج :

\section{1- التعر يف الصحيح للدعوة:}

r- توضيح الأصل الشرعي للدعوة الإسلامية.

r- إيجاد دراسـة علميلة توضح أهمية الدعوة الإسلامية.

ع- إيجاد أهمية الدعوة و معر فة الأسباب الهوصلة لها.

ه- معرفة الأسباب التي تؤدي لنجاح الدعوة.

\section{المناقشة:}

ا- رغبة الباحثة في دراسة و معر فة أهمية الدعوة الإسلامية.

r- أثر الدعوة في إصدلاح المجتهـع.

r- ضرورة التأصيل الشرعي للعمل الدعوي.

ع- الحاجة لبيان الصلة بين الدعوة وحياة الهسله.

ه- تطوير العهل الدعوي للدعاة.

أهم أسئلة المناقشة وهي:

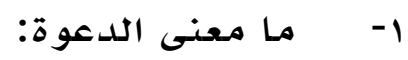

r- الأسباب التي تؤدي إلى قيام منهج صحيح للدعوة؟

r- كيفية تحقيق منهاج صحيح للدعوة وتصحيح العقدية؟

ع- هل يوجد علاقة ارتباطية بين الدعوة والعقيدة الصحيحة؟؟

ه - معر فة الوسائل والأساليب التي تدعو للدعوة الصحيحة؟

צ- معرفة آثار الدعوة على الفرد و الجماعة؟

الملاحقق:

ا- الإثـارة إلى مواضع الآيات القر آنية من سورها في كتاب الله 
العزيز بذكر اسهم السورة ورقم الآية وراعيت في كتابتها الرسم

$$
\text { العثماني. }
$$

r- الرجوع في بيان معنى الآيات وو جـه الدلالة منها إلى كتب التفسير المعتبرة.

r- عزو الأحاديث الشريفة إلى مصادرها الأصلية من الصحاح والسنن

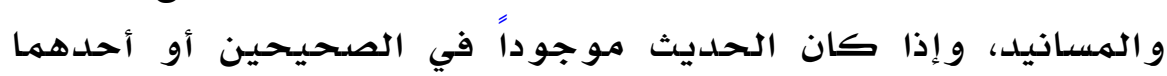
فإني أكتفي بعزوه إليهما، و إذا كان الحديث في غير الصديث إديحين

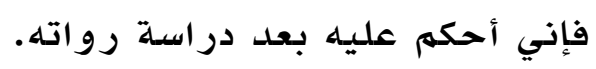

ع- الرجوع في بيان معنى الأحاديث ووجه الدلالة إلى كتب شروح

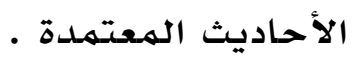

ه- تخريج الأمثال و الأشعار من مصادرها الأصلية و التعريف بالبلدان

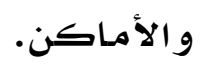

ج- جرى بيان غريب الألفاظ و إيضاحها من الكتب المعتمدة. V- رتبت المر اجع والمصادر التي استخدمتها في البحث تر تيباً هجائياً. ي- قمت بوضع الفهارس العلميلة ورتبتها على النحو التالي: الملاحق:

$$
\begin{aligned}
& \text { أ - فهر الآيات القر آنية. } \\
& \text { ب - فهر س الأحاديث النبو ية. } \\
& \text { ج - فهرس الآثار. } \\
& \text { د - فهرس الأمثال. } \\
& \text { هـ - فهرس الأشعار. } \\
& \text { و - فهرس الأماكن و البلدان. } \\
& \text { ز - فهر - فهرس المفردات اللماسن والبلية. } \\
& \text { ح - فهرس المصادر و الهر اجـع. } \\
& \text { ط - فهر س الموضوعات. }
\end{aligned}
$$




\section{: إخلاهية}

\section{الدعوة الإسلامية منهاج حياة وياتي أهميته من:}

- - أن الدعوة إلى الله واجب كل مسلهم ومسلهمة في كل زمان... وفي

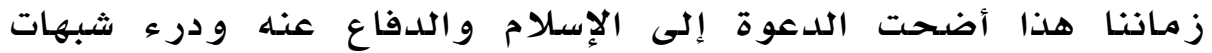

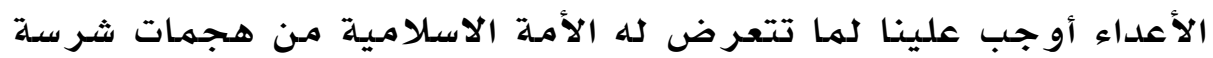
من أعداء الاسلام والحاقدين عليه والحاسدين للحق الذي جاء بهـ. - موالدعوة الى الله شرف عظيهم لصساحبها: قال تعالى:

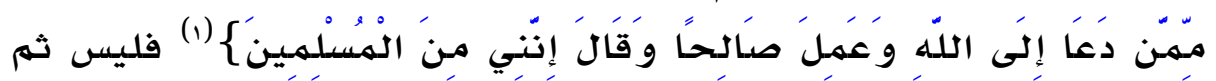

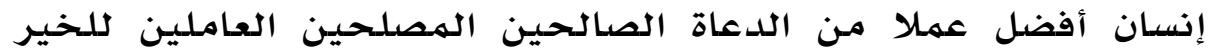

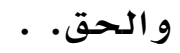

- الدعوة إلى الله ثوابها كبير و عظيه، وحديث رسول الله صلى الله عليه

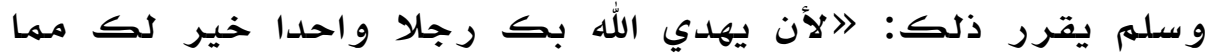

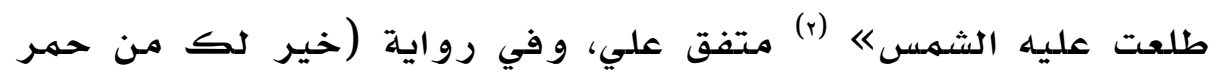
النعمم) (1)

- والدعوة إلى الله هي الطريق الصحيح من ألزم الأمور وسط هذا

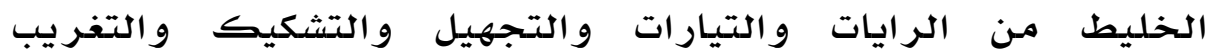
و الانحر اف.

- - الدعوة الى الله مرحلة مهمـة من مراحل العمل الإسلامي الجـاد وهي

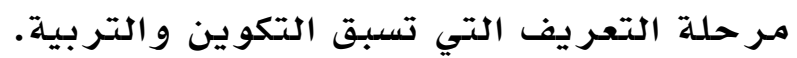

$$
\text { (1) متفق عليه. }
$$




\section{المراجع و المصادر}

القر آن الكريم.

كتب السنة.

ا- أسساس البـلاغة، أبو اقاسهم محمهود بن عمر بن محمد بن عمر

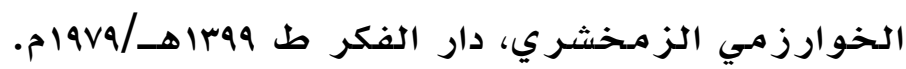

ץ- الأسسس العلهية لهنهج الدعوة الإسـلاميـة، أ.د. عبدالرحيم م بن محهد

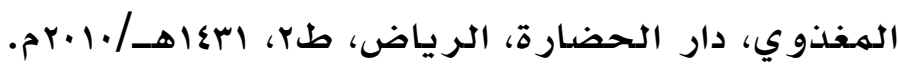

r- بحوث في عقيدة أهل السنـة والجماعة، دار الوطن للنشر، طا، . $1 \leqslant 1 \mathrm{r} / \mathrm{q} / \mathrm{ir}$

ع- تاج العروس مـن جواهر القاموس ، محمهد الحسيني الزبيدي، مجمهو عة من الهـحققين، دار الهداية.

- التخطيط للدعوة الإسـلاميـة و أهميته، عبلدرب النبي علي أبو السعود، دار التوفيق النهو ذجية للطباعة، القاهرة، طا، باعاهـ/994ام. ص : 19 النهموذجية للطابعة، القاهرة. צ- جامـع بيان العلهم وفضله، عبدالبر ، تحقيق: أبي الأثبـال الزهيري ، دار ابن الجوزي، الهملكة العربية السعودية، طا، عاعاهـ، ع99ام. - - الدعوة الإسـلامية دعوة عالميلة، محمد عبدالرحهن الراوي، الدار

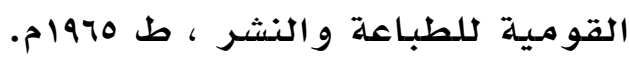

لدعوة و الإنسان، عبدالله يوسف الشاذلي، الهكتبـة القومية الحديثة، طنطا، طا.

ه- القاموس المحيط مادة الفيروز آبادي ، مؤسسة الرسالة للطباعة

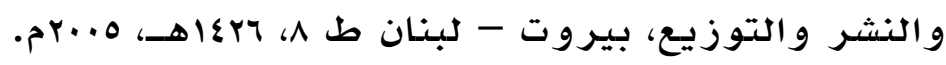

• - لسـان العرب، محمدل بن مكرم بن منظور، طا، دار صسادر، بيروت. 
11- مجموع الفتاوي، تقي الدين أبو العباس أحمد بن عبدالحليهم بن

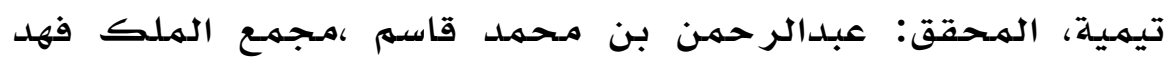

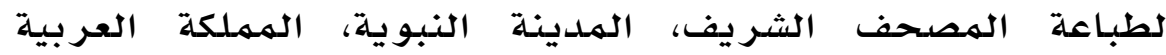

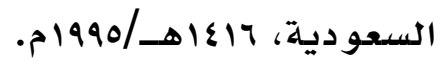

rا- المدخل إلى علهم الدعوة، محمد البيانوذي، دار الرسالة طا، 1990م. rا- مستلزمات الدعوة في العصر الحاضر، علي صالح الهرشد، مكتبة

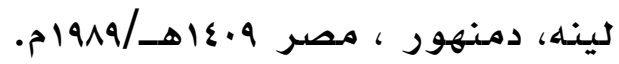

